\title{
Social Responsibility, Organizational Commitment, and Organizational Performance: Food Processing Enterprises in the Mekong River Delta
}

\author{
Thanh Hung NGUYEN*, Van Binh TU ${ }^{* *}$
}

Received: December 10, 2019 Revised: December 18, 2019 Accepted: December 28, 2019

\begin{abstract}
This study aims to measure the relationship between corporate social responsibility (CSR) and affective commitment (ACO), normative commitment (NCO), and organizational performance in food processing enterprises (FPEs) in the Mekong River Delta, Vietnam. To test the initial model proposed in this paper, a total of 422 owners, directors and managers of FPEs were interviewed from some provinces in the Mekong River Delta. The method of exploratory factor analysis (EFA) is initially employed, then confirmatory factor analysis (CFA) and structure equation modelling (SEM) are used. The results of SEM showed that higher affective commitment was correlated with normative commitment. The results showed that four aspects of CSR toward employees, customers, environment and legal are significant factors. As a result, ACO and $\mathrm{NCO}$ act as mediators between CSR and organizational performance. This finding provides strong evidence of the important role of CSR to support positive impacts on ACO, NCO, and orgazational performance (OP). In addition, the success of the organizational performance is also found by contributions of CSR and NCO to its changes. Although ACO does not directly affect performance, it has a positive effect on the NCO. Therefore, it is necessary to enhance the implementation of CSR to promote implementation of organizational commitments.
\end{abstract}

Keywords: CSR, Commitment, Performance, Enterprise, Vietnam

JEL Classification Code: M110, M120, M140

\section{Introduction}

Corporate social responsibility (CSR) has become increasingly popular and seeks to link sustainable development with the core values of an enterprise to create a common value for the enterprise as well as society. Carroll (1991) argued that CSR involves the business of economic interests, observance of the law, morality, and social support. In fact, it is very easy to misunderstand the concept of CSR as the sense of "tradition" includes an activity to solve the social problems and charity. While very few enterprises see benefits of CSR as an increase in labor productivity, it does reduce the amount of leave days that

${ }^{*}$ First Author. School of Economics and Law, Tra Vinh University, Vietnam. Email: nthung@tvu.edu.vn

${ }^{*}$ Corresponding Author. University of Economics Ho Chi Minh City \& CFVG, Vietnam [Postal Address: 59C Nguyen Dinh Chieu Street, District 3, Ho Chi Minh City, 700000, Vietnam] Tel: +84 938825815 Email: tuvanbinh@gmail.com or binhtv@ueh.edu.vn ๑ Copyright: Korean Distribution Science Association (KODISA)

This is an Open Access article distributed under the terms of the Creative Commons Attribution NonCommercial License (https:///creativecommons.org/icenses/by-nc/4.0/) which pemits unrestricted noncommercial use, distribution, and reproduction in any medium, provided the original work is properly cited. employees take and reduces quitting. It also causes a reduction in costs of hiring and training new employees and increases sales growth.

As argued by Bagnoli and Watts (2003), once CSR is concerned, it contributes to attract more socially responsible customers and to generate advantages of competition. In researches on CSR in Vietnam, there are currently concerned, Long (2015) and Binh and Tien (2019) found evidence of a significantly positive relationship between CSR and firm performance. However, some authors still argue that conclusions of enterprises using CSR strategies to gain performance are less clear (Conesa, Acosta, \& Manzano, 2017). This study seeks to remove these doubts.

In fact, in the last three decades, many researches have investigated the relationship between CSR and firm performance, in which performance was measured as financial (e.g., ROA, ROE and profit) and market indicators (e.g., sales growth, productivity growth). This paper takes a different approach to use organizational performance as a proxy to determine the effectiveness of the company. In 
addition to investigating how CSR impacts organizational performance, it also investigates the affective and normative commitment of employees working in food processing enterprises (FPEs). In this paper, we seek to understand how affective commitment influences normative commitment and organizational performance as well as its impact on the normative commitment to organizational performance.

The next section describes a conceptual framework that is used to develop the model research proposition. Then, details regarding the data collection from a survey is described, and finally, the results are discussed, and conclusions are presented.

\section{Framework of Concept}

\subsection{Corporate Social Responsibility}

There are various concepts of CSR. According to Mason and Simmons (2014), CSR includes two points: (i) external elements consist of relationships between enterprises and community and (ii) inner aspects focus on functional benefits, economics, and psychology.

Martín Castejón and Aroca López (2016) employed three dimensions (i.e., economics, society, and environment) to evaluate the CSR of SMEs, in which the social dimension considers employees who are working in the enterprise, and the environmental dimensions refer to ideas and actions on waste treatments to limit risks of the polluted environment. Transparency of environmental issues by the firm determines its implication levels with respect to legal requirements. In fact, the firm's consideration of CSR is typically in an attempt to optimize returns to stakeholders. Once customers realize that the firm is socially responsible, they then have positive sympathy. CSR not only offers what the firm considers to be benefits of customers, employees, and environment, but it also ensures that legal activities are met that are required by the government. As arguments stated, four main components relevant to CSR employed in the proposed model are the CSR to employees, to customers, to the environment, and to legal issues.

According to Skudiene and Auruskeviciene (2012), CSR has an involvement to issues of stakeholders and an impact on employees' working motivation. Based on the research of 386 respondents who was working at German firms, Mory, Wirtz, and Göttel (2015) found a strong influence of CSR on employees' affective commitment and normative commitment of the organization. Accordingly, the affective commitment and the normative commitment are considered in this paper. However, these two factors are questionable for FPEs in Vietnam and will be tested through two hypotheses below:
H1: A positive change in CSR causes a significantly positive effect on affective commitment

H2: A positive change in CSR causes a significantly positive effect on normative commitment

\subsection{Organizational Commitment}

Organizational commitment is a spiritual relationship between employees and organizations that reduce possible risks of leaving the organization by employees. The structure of the organizational commitment can be seen in different aspects. For example, the affective commitment mentions emotional engagement of staff, involving an employee for the organization's objectives, while the normative commitment denotes an attachment of emotion to, involvement with, and identification to the organization (Meyer, Stanley, Herscovitch, \& Topolnytsky, 2002).

The affective commitment and the normative commitment may be implied in the organizational commitment. The affective commitment refers to an emotional attachment of staff. Once the commitment has been completed, the firm has an additional chance to create loyalty from their employees. However, the firm must also be strict to keep commitment, because when the commitment obligation is complete, employees believe that they can prolong their work at the same company.

Basically, the normative commitment refers to a commitment in which a a person will stay with the same enterprise to fulfill an obligation. Accordingly, the normative commitment has the general value of loyalty and responsibility. Meyer, Stanley, Herscovitch, and Topolnytsky (2002) mentioned that the normative commitment and the affective commitment by scholars have a strong correlation, while the continuance commitment was found to have no significant effect (Albdour, Nasruddin, \& Lin, 2010). As a result, this paper only assumes that the normative commitment and the affective commitment are representative of organizational commitment and that affective commitment is enclosed as a mediator between CSR and the normative commitment. Once the employee has affective commitment, he/she will work harder to meet the requirements of the organization (Meyer \& Smith, 2000; Meyer, Stanley, Herscovitch, \& Topolnytsky, 2002). As stated, the affective commitment plays an important role in influencing normative commitment. Based on arguments, the following hypothesis is claimed:

H3: A change in affective commitment causes a positive impact on normative commitment 


\subsection{Organizational Performance}

To investigate the relationship between CSR and firm performance, many scholars use various measures to conceptualize firm performance. For example, Watson (2007) and Binh and Tien (2019) employed indicators such as sales growth productivity, and labor growth as well as ROEs as a proxy of firm performance. Yang and Ju (2017) used a Likert scale from 1 being much lower to 7 being much higher of four observed variables to measure firm performance, of which enterprises were asked to evaluate ROE, achievement to meet goals and objectives of firm, the levels of success on overall profitability, and sales growth compared to competitors.

In this paper, we employ organizational performance based on the argument of Delaney and Huselid (1996), which states that a perceptual measure is derived from questions that have responses rated from 1 (unlikely) to 7 (very likely). As found by Dollinger and Golden (1992), organizational performance is positively correlated with firm performance. Based on these findings, organizational performance was used in this paper. Its measure is rated by a seven-point Likert scale. To gain evidence to confirm a relationship between CSR and organizational performance, Imran Ali, Rehman, Ali, Yousaf, and Zia (2010) used the sample of 371 professionals working at enterprises in Pakistan with structure equation modelling (SEM), and they confirmed an accepted hypothesis of impacting CSR on the organizational performance. Based on this, we generated the following hypothesis:

H4: Concern regarding CSR is positively correlated with organizational performance.
Sheldon (1971) argued that members' engagement in the organization not only consider the organizational performance but also helps to measure employee performance. Once the members are aware of what the socially responsible activities of the enterprise, they can remain happier and stay longer at the same company. This means that only when members positively recognize organizations can they make every effort to help organizations achieve better efficiency. Additionally, the strength of the commitment to membership would affect the goals of the organization as well as the employee's job satisfaction.

Studies have shown that trust in an organization is a factor that positively impacts organizational performance (McWilliams \& Siegel, 2000). Bakiev (2013) and Mansour, Gara, and Gaha (2014) demonstrated that organizational commitment has a significantly positive impact on organizational performance. Therefore, the following hypotheses were created:

H5: Affective commitement is positively correlated with organizational performance.

H6: Normative commitment is positively correlated with organizational performance.

Based on previous arguments of scholars, the proposition of the initial model is summarized in figure 1, and the four components of CSR - that is, to employees, to customers, to the environment, and to legal considerations - are shown. Affective and normative commitment are also added to the model, and their relationships with organizational performance are hypothesized. They can also bring positive results to the enterprise once there is a positive impact of CSR on them.

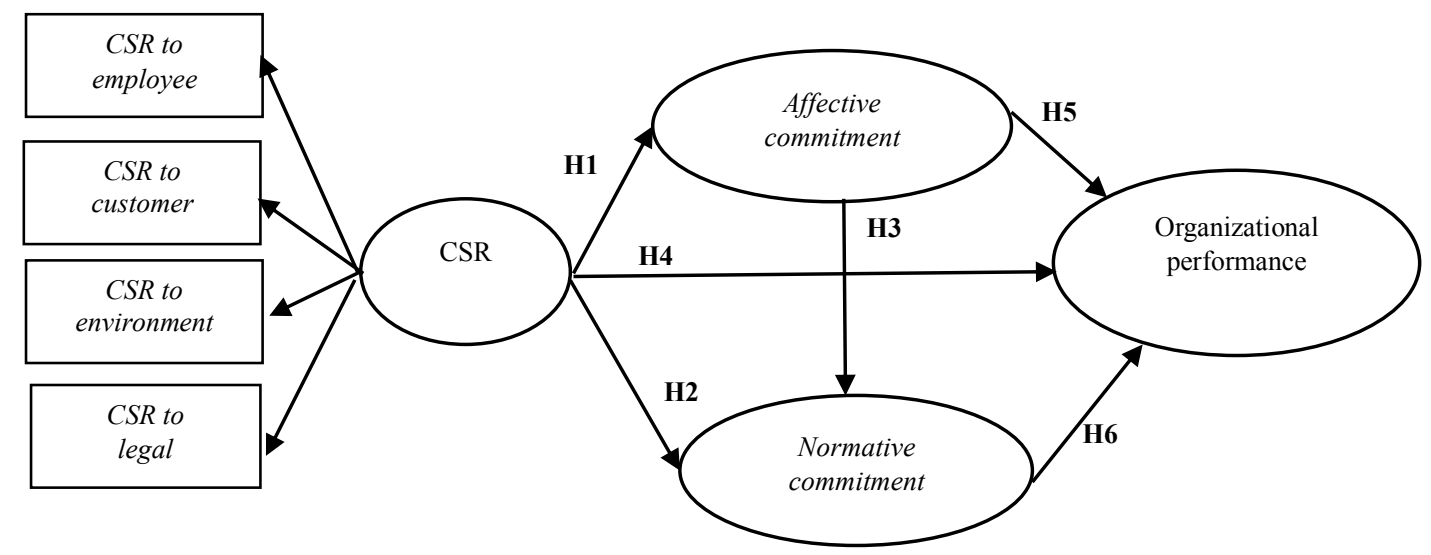

Figure 1: Proposed research model 


\section{Data and Measurements}

FPEs were interviewed during the first four months of 2019. The sampling is based the list of total enterprises, in which FPEs are considered and selected, and 422 acceptable questionnaires were obtained. All of these enterprises are located in seven of thirteen provinces in the MRD, including Dong Thap, Soc Trang, Tien Giang, Bac Lieu, Ca Mau, Tra Vinh, and Can Tho City. Most of the questions in the questionnaire were measured using a seven-point Likert scale in addition to requesting demographic information.

CSR is measured using arguments of Carroll (1991), Freeman (2004) and Turker (2009). As previously stated, CSR is broken into CSR to customers, CSR to employees, CSR to the environment, and CSR to legal issues. Each dimension employs 5 items or observed variables.

Affective and normative organizational commitment variables observed in each factor are based on references of previous authors, in which Meyer, Stanley, Herscovitch, and Topolnytsky (2002) are recruited, and each dimension consists of five items.

Organizational performance is measured based on Dollinger and Golden (1992), Delaney and Huselid (1996), and Richard, Devinney, Yip, and Johnson (2009). There are six items employed in the factor to evaluate the organizational performance.

In total, there were 36 observed variables designed in the questionnaire, and their reliability was determined using Cronbach's alpha. As a result, the destination test confirmed that 31 observed variables could be accepted for inclusion within exploratory factor analysis (EFA), confirmatory factor analysis (CFA), and structure equation modelling (SEM).

\section{Empirical Results}

The final sample size (i.e., 422) was distributed into four main types of enterprises, as shown in figure 2 . The ownership form of the joint stock company accounts for the highest percentage (45\%), followed by limited companies $(31 \%)$, private enterprises $(18 \%)$, and microenterprises $(6 \%)$.

In addition, the sizes of the enterprises based on the number of employees were identified in figure 3 . Enterprises with more than 100 employees comprised the highest percentage (57\%), followed by $10-<50$ employees $(18 \%), 50-<100$ employees $(15 \%)$, and $<10$ employees $(10 \%)$. Therefore, the responses adequately represented the different types and different sizes of enterprises and therefore can be used to generate comments for policy makers once the analysis results are understood.

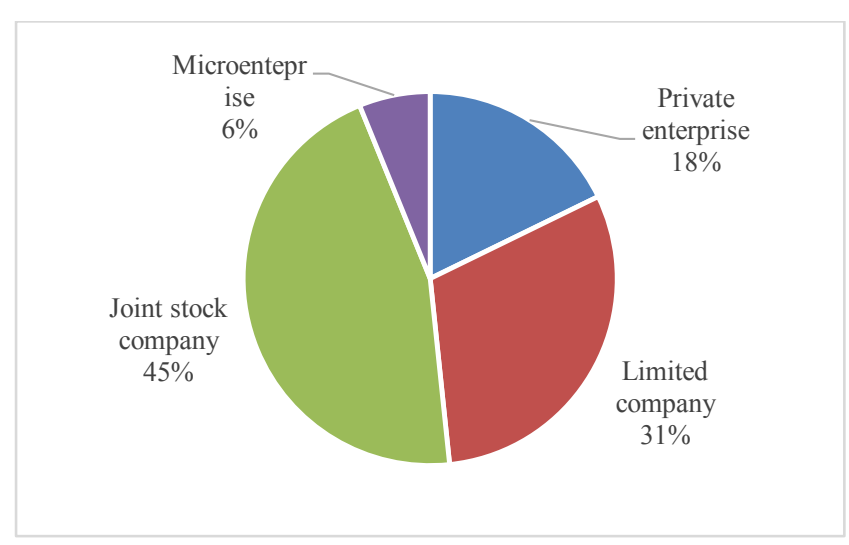

Figure 2: Type of enterprises

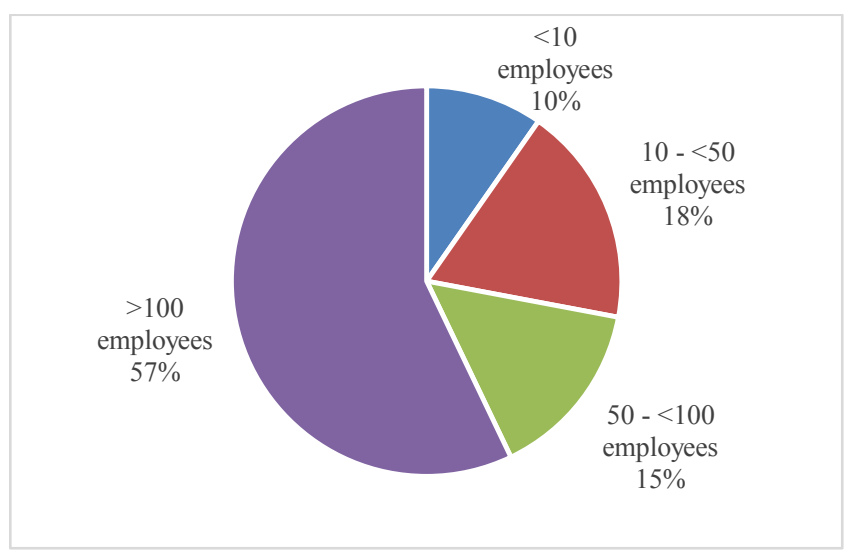

Figure 3: Enterprise size based on number of employees

CFA was first employed to test the model's goodness of fit. As shown in figure 3, all indicators of CFI, TLI, GFI, and RMSEA met the standardized requirements of the method that is, TLI $=0.946$ and CFI $=0.937$, which were both greater than the standard value of 0.90 , and RMSEA = 0.053 , which was less than a required level of 0.08 ( Hu \& Bentler, 1999). Overall, the CFA results confirm that the proposed model produced acceptable goodness-of-fit values. As depicted in figure 4, most of the factors have highly significant correlations with each other-for example, there were high correlations between CSR to employees and normative commitment (0.843) and between CSR to employees and organizational performance (0.739). In addition, there is a high correlation between affective and the normative commitment $(0.804)$, which is consistent with the previous argument of a strong correlation between these components made by Meyer, Stanley, Herscovitch, and Topolnytsky (2002) 


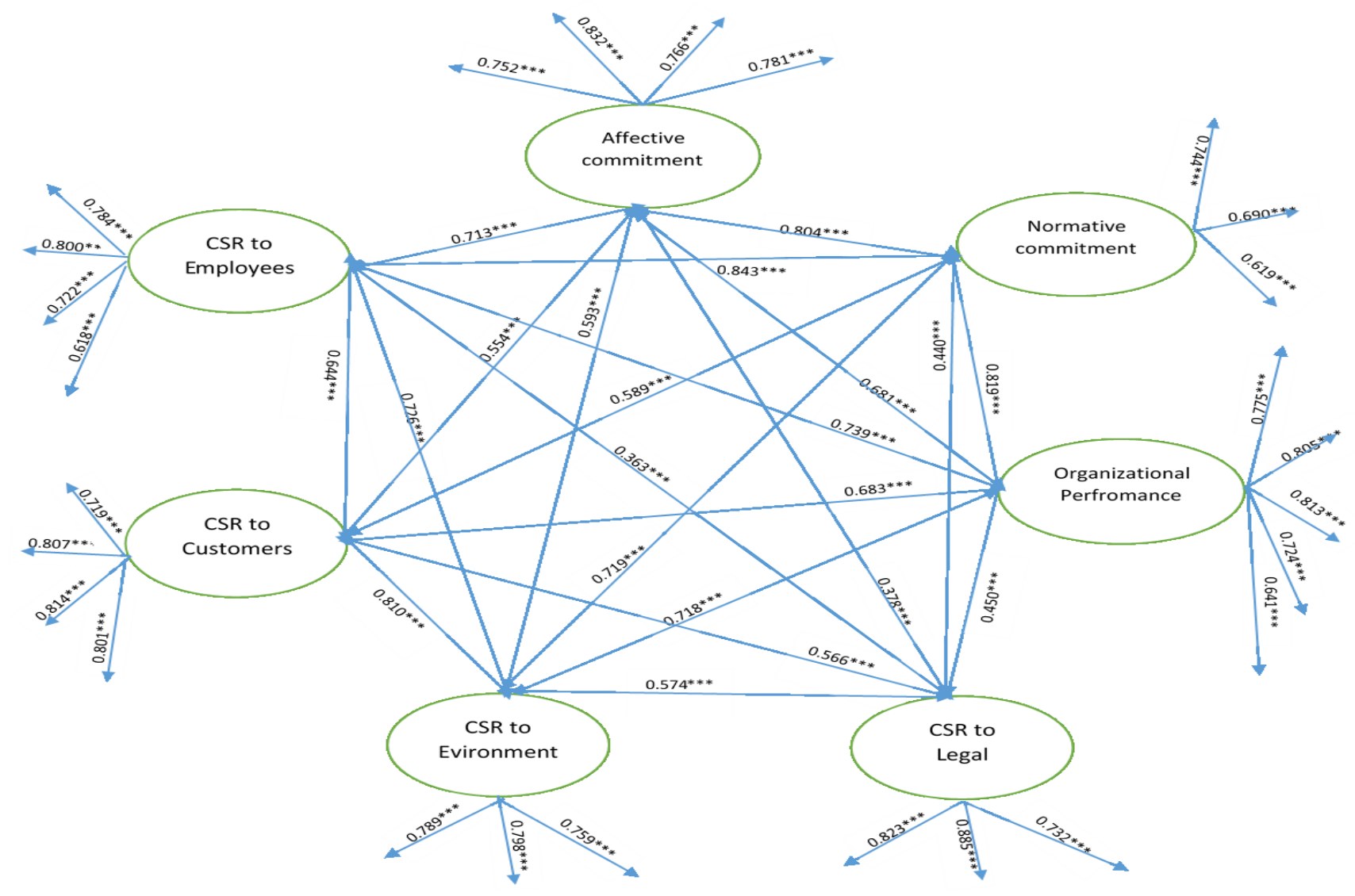

Chi-square $=612.788 ; \quad \mathrm{df}=278 ; \quad$ Chi-square $/ \mathrm{df}=2.204 \quad \mathrm{n}=422$

GFI $=0.895 ; \quad$ TLI $=0.946 ; \quad$ CFI $=0.937 \quad$ RMSEA $=0.053 ; \quad \mathrm{p} \leq 0.001(* * *)$

Note: *** significant at $1 \% ; * *$ significant at $5 \% ; *$ significant at $10 \%$

Figure 4: First-order confirmatory factor analysis

Testing reliability by Cronbach's alpha: Based on the reuslts from the CFA and the reliability test, the variance extracted from the factors in the model converged and are acceptable to be used in further analysis methods (Table 1). As a result, these items can be added to the proposed model.

Table 1: Result testing reliability by Cronbach's alpha

\begin{tabular}{|c|c|c|c|c|c|}
\hline \multirow{2}{*}{ Factors } & \multirow{2}{*}{ Items } & \multicolumn{2}{|c|}{ Reliability } & \multirow{2}{*}{$\begin{array}{c}\text { Variance extracted (\%) } \\
\text { ( } \rho v c)\end{array}$} & \multirow{2}{*}{ Decision } \\
\hline & & Cronbach's alpha & Total (pc) & & \\
\hline CSR to employee (CSRE) & 4 & 0,814 & 0,814 & $54 \%$ & \multirow{4}{*}{ Accepted } \\
\hline CSR to customer (CSRC) & 4 & 0,863 & 0,866 & $62 \%$ & \\
\hline CSR to environment (CSRE) & 3 & 0,824 & 0,826 & $62 \%$ & \\
\hline CSR to legal (CSRG) & 3 & 0,851 & 0,849 & $65 \%$ & \\
\hline ACO (affective commitment) & 4 & 0,862 & 0,864 & $61 \%$ & \multirow{2}{*}{ Accepted } \\
\hline NCO (normative commitment) & 3 & 0,769 & 0,771 & $53 \%$ & \\
\hline PER (organizational performance) & 5 & 0,863 & 0,868 & $57 \%$ & Accepted \\
\hline
\end{tabular}

The results of the SEM are shown in figure 5, which presents the relationships between four components of CSR to ACO, NCO, and PER. Based on indicators of GFI, TLI, CFI, and RMSEA, the model is highly significant and appropriate. This final result is important when drawing conclusions in the next section. 


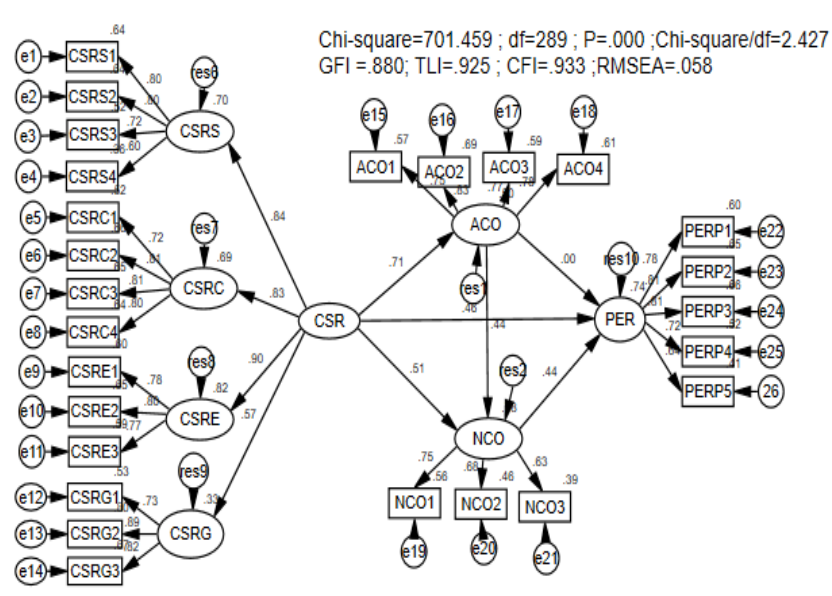

Figure 5: Result of Structural Equation Modelling (SEM)

Table 2: Result of testing hypotheses (standardized)

\begin{tabular}{|lc|r|r|r|r|}
\hline \multicolumn{2}{|c|}{ Relationship } & $\begin{array}{c}\text { Standardized } \\
\text { Coefficient }\end{array}$ & \multicolumn{1}{c|}{ S.E. } & \multicolumn{1}{c|}{ C.R. } & P \\
\hline $\mathrm{CSR} \rightarrow \mathrm{ACO}$ & 0.710 & 0.08 & 10.744 & $* * *$ \\
\hline $\mathrm{CSR} \rightarrow \mathrm{NCO}$ & 0.515 & 0.09 & 6.478 & $* * *$ \\
\hline $\mathrm{ACO} \rightarrow \mathrm{NCO}$ & 0.440 & 0.071 & 5.861 & $* * *$ \\
\hline $\mathrm{CSR} \rightarrow \mathrm{PER}$ & 0.458 & 0.111 & 4.556 & $* * *$ \\
\hline $\mathrm{ACO} \rightarrow \mathrm{PER}$ & -0.002 & 0.079 & -0.018 & 0.986 \\
\hline $\mathrm{NCO} \rightarrow$ & $\rightarrow$ PER & 0.445 & 0.136 & 3.186 & $* * *$ \\
\hline
\end{tabular}

Note: $* * *$ Significant level at $1 \%$.

The standardized coefficients are shown in table 2. There are mostly positive relationships between CSR and ACO, NCO, and PER, in which CSR has the highest impact on ACO (0.710). Because these relationships are positive, an increase in CSR corresponds with increases in ACO, NCO and PER.

While there is not sufficient evidence to confirm a significant impact of ACO on PER, the impact of ACO on NCO is accepted. This is explained through CSR by the impact of NCO on PER. As a result, higher CSR in the enterprise enhances engagement regarding affective and normative commitment. Although there is not evident to confirm a significant relationship between ACO and PER, this can motivates employees to complete obligations and improve organizational performance (Mory, Wirtz, \& Göttel, 2015).

\section{Discussion}

The findings of this study are interesting and add to empirical evidence of enteprises in Vietnam, particularly FPEs. Accordingly, CSR has significant impacts on the affective commitment and the normative commitment, which is consistent with Mory, Wirtz, and Göttel (2015). In addition, a positive change in the affective commitment significantly caused increases in the normative commitment, which is consistent with Meyer and Smith (2000) and Meyer, Stanley, Herscovitch and Topolnytsky (2002). In parallel, higher consideration of CSR is correlated with higher organizational performance, which agrees with Ali, Rehman, Ali, Yousaf and Zia (2010), Mustafa, Othman, and Perumal (2012), and Binh and Tien (2019).

Although normative commitment has a significantly positive impact on organizational performance, the finding of a relationship between affective commitment and organizational performance is not supported. This can be explained because a higher consideration of CSR in enterprises creates more employee engagement with affective and normative commitment (Ali, Rehman, Ali, Yousaf, \& Zia, 2010; Mustafa, Othman, \& Perumal, 2012). Affective and normative commitment can present sufficently different correlations with other factors, such as organizational performance. They demonstrate sufficiently different correlations with other variables, particularly for variables that support outcomes of commitment (Cohen, 1996).

\section{Conclusion}

To test the initial model proposed in this paper, a total of 422 owners, directors and managers of FPEs were interviewed in some provinces in the MRD. The results of SEM showed that higher affective commitment was correlated with normative commitment. This is important for entrepreneurs and policy makers to consider when planning promotion programs to stimulate works of employees in terms of normative commitment. This leads to improvements in organization performance.

In addition, we have presented strong evidence of a positive influence of normative commitment to CSR, while CSR includes four components: CSR to employees, CSR to customers, CSR to the environment, and CSR to legal issues. This finding also proves that the organizational performance is positively affected by CSR, and this result again agrees with previous studies, which is an important finding for FPEs in the MRD.

\section{References}

Al-bdour, A., Nasruddin, E., \& Lin, S. (2010). The relationship between internal corporate social responsibility and organizational commitment within the banking sector in Jordan. International Journal of 
Human and Social Sciences, 5(7), 932-951. https://doi.org/10.5539/ijbm.v7n16p89

Ali, I., Rehman, K. U., Ali, S. I., Yousaf, J., \& Zia, M. (2010). Corporate social responsibility influences, employee commitment and organizational performance. African Journal of Business Management, 4(12), 27962801.

Bagnoli, M., \& Watts, S. G. (2003). Selling to socially responsible consumers: Competition and the private provision of public goods. Journal of Economics and Management Strategy, 12(3), 419-445. https://doi.org/10.1162/105864003322309536

Bakiev, E. (2013). The Influence of Interpersonal Trust and Organizational Commitment on Perceived Organizational Performance. Journal of Applied Economics and Business Research, 3(3), 166-180.

Binh, T., \& Tien, H. V. (2019). Corporate social responsibility and performance of SMEs in Ho Chi Minh City (Vietnam). International Journal of Management and Enterprise Development, 18(4), 277. https://doi.org/10.1504/ijmed.2019.10022922

Carroll, A. B. (1991). The pyramid of corporate social responsibility: Toward the moral management of organizational stakeholders. Business Horizons. https://doi.org/10.1016/0007-6813(91)90005-G

Cohen, A. (1996). On the discriminant validity of the Meyer and Allen measure of organizational commitment: How does it fit with the work commitment construct? Educational and Psychological Measurement, $\quad 49(3), \quad$ 252-276. https://doi.org/10.1177/0013164496056003011

Conesa, I. M., Acosta, P. S., \& Manzano, M. P. (2017). Corporate social responsibility and its effect on innovation and firm performance: An empirical research in SMEs. Journal of Cleaner Production, 142(1), 23742383.

Corporate social responsibility and performance of SMEs in Ho Chi Minh City (Vietnam). (n.d.).

Delaney, J.T., \& Huselid, M. A. (1996). The impact of human resource management practices on perceptions of organizational performance. Academy of Management Journal, 39(4), 949-969. https://doi.org/10.2307/256718

Delaney, J. T., \& Huselid, M. A. (1996). The impact of human resource management practices on perceptions of organizational performance. Academy of Management Journal, 39(4), 949-969. https://doi.org/10.2307/256718

Dollinger, M. J., \& Golden, P. A. (1992). Interorganizational and Collective Strategies in Small Firms: Environmental Effects and Performance. Journal of Management, 18(4), 695-715. https://doi.org/10.1177/014920639201800406
Freeman, R. E. (2004). The Stakeholder Approach Revisited. Zeitschrift Für Wirtschafts-Und Unternehmensethik, 5(3), 228-241. https://doi.org/10.3763/jsfi.2010.0008

Hu, L. T., \& Bentler, P. M. (1999). Cutoff criteria for fit indexes in covariance structure analysis: Conventional criteria versus new alternatives. Structural Equation Modeling, 6(1), 1-55. https://doi.org/10.1080/10705519909540118

Long, H. C. (2015). The impact of market orientation and corporate social responsibility on firm performance: Evidence from Vietnam. Academy of Marketing Studies Journal, 19(1), 265-277.

Mansour, N., Gara, E., \& Gaha, C. (2014). Getting inside the black box: HR practices and firm performance within the Tunisian financial services industry. Personnel Review, 43(4), 490-514.

Martín Castejón, P. J., \& Aroca López, B. (2016). Corporate social responsibility in family SMEs: A comparative study. European Journal Of Family Business, 6(1), 2131. https://doi.org/10.24310/ejfbejfb.v6i1.5044

Mason, C., \& Simmons, J. (2014). Embedding Corporate Social Responsibility in Corporate Governance: A Stakeholder Systems Approach. Journal of Business Ethics, 119(1), 77-86. https://doi.org/10.1007/s10551012-1615-9

McWilliams, A., \& Siegel, D. (2000). Research notes and communications. Corporate social responsibility and financial performance: correlation or misspecification? Strategic Management Journal, 609(January 1999), 603-609. https://doi.org/10.1002/(SICI)10970266(200005)21

Meyer, J. P., \& Smith, C. A. (2000). HRM Practices and Organizational Commitment: Test of a Mediation Model. 17(4), 319-331.

Meyer, J. P., Stanley, D. J., Herscovitch, L., \& Topolnytsky, L. (2002). Affective, continuance, and normative commitment to the organization: A meta-analysis of antecedents, correlates, and consequences. Journal of Vocational Behavior, 61(1), 20-52. https://doi.org/10.1006/jvbe.2001.1842

Mory, L., Wirtz, B. W., \& Göttel, V. (2015). Factors of internal corporate social responsibility and the effect on organizational commitment. International Journal of Human Resource Management, 27(13), 1393-1425. https://doi.org/10.1080/09585192.2015.1072103

Mustafa, S. A., Othman, A. R., \& Perumal, S. (2012). Corporate Social Responsibility and Company Performance in the Malaysian Context. Procedia Social and Behavioral Sciences, 65(ICIBSoS), 897-905. https://doi.org/10.1016/j.sbspro.2012.11.217

Richard, P. J., Devinney, T. M., Yip, G. S., \& Johnson, G. (2009). Measuring organizational performance: 
Towards methodological best practice. Journal of Management, $\quad 35(3)$, 718-804. https://doi.org/10.1177/0149206308330560

Sheldon, M. E. (1971). Investments and involvements as mechanisms producing commitment to the organization. Administrative Science Quarterly, 143-150.

Skudiene, V., \& Auruskeviciene, V. (2012). The contribution of corporate social responsibility to internal employee motivation. Baltic Journal of Management, $7(1)$ 49-67. https://doi.org/10.1108/17465261211197421
Turker, D. (2009). Measuring corporate social responsibility: A scale development study. Journal of Business Ethics, 85(4), 411-427.

Watson, J. (2007). Modeling the relationship between networking and firm performance. Journal of Business Venturing, 22(6), 852-874. https://doi.org/10.1016/j.jbusvent.2006.08.001

Yang, Y., \& Ju, X. F. (2017). Entrepreneurial Orientation and Firm Performance: Is Product Quality a Missing Link? Entrepreneurship Research Journal, 8(1), 1-13. https://doi.org/10.1515/erj-2017-0091 